\title{
PENERAPAN METODE PROGRAMMING FRAMEWORK PADA PUSAT PENGOLAHAN DAN PENELITIAN KERANG DI KAMPUNG KERANG IJO
}

\author{
Kevin Gumilang ${ }^{1)}$ \\ 1)Program Studi S1 Arsitektur, Fakultas Teknik, Universitas Tarumanagara, kevingumilang30@gmail.com
}

Masuk: 03-07-2021, revisi: 15-08-2021, diterima untuk diterbitkan: 23-10-2021

\begin{abstract}
Abstrak
Pencemaran limbah merupakan fenomena global yang belakangan ini menjadi permasalahan bagi perkotaan, salah satu limbah yang memberikan dampak cukup besar terhadap lingkungan adalah limbah yang berada di Teluk Jakarta. Salah satu lokasi yang merasakan langsung dampak tersebut adalah Kampung Kerang ljo, Muara Angke, Pluit, Jakarta Utara. Fenomena yang menarik di Kampung Kerang ljo adalah Sebagian besar masyrakatnya berprofesi sebagai Nelayan Kerang dan Pengupas Kerang yang dagingnya dijual di pasaran. Lalu muncul masalah di kawasan ini yaitu Limbah Kulit Kerang yang menumpuk. Jika Hal ini terus terjadi, maka kondisi ini akan memperburuk kondisi ekologi setempat hingga ke ekologi yang lebih makro. Melalui metode Programming Framework dan berbagai penelitian, memungkinkan untuk mendesain bangunan yang membudidayakan, mengolah, dan memanfaatkan kerang untuk mengurangi dampak buruk ekologi pada kawasan tersebut. Pengolahan berkelanjutan Kulit Kerang agar dapat dimanfaatkan secara maksimal, dan meminimalkan limbahnya terhadap lingkungan. Dengan adaptasi tersebut, tentu mampu mengurangi dampak buruk terhadap Ekologi di kawasan tersebut.
\end{abstract}

Kata Kunci: Pengolahan Kerang, Limbah Kulit Kerang, Kampung Kerang ljo, Ekologi.

\begin{abstract}
Waste pollution is a global phenomenon that has recently become a problem for cities, one of the wastes that has a considerable impact on the environment is waste in Jakarta Bay. One of the locations that directly felt the impact was Kampung Kerang ljo, Muara Angke, Pluit, North Jakarta. An interesting phenomenon in Kampung Kerang ljo is that most of the people work as Shellfish Fishermen and Shellfish Peelers whose meat is sold in the market. Then a problem arose in this area, namely the accumulation of seashell waste. If this continues to happen, then this condition will worsen the local ecological conditions to a more macro ecology. Through the Programming Framework method and various studies, it is possible to design buildings that cultivate, cultivate, and utilize shellfish to reduce the adverse ecological impact on the area. Continuous processing of seashells so that they can be utilized optimally, and minimize their waste on the environment. With this adaptation, it is certainly able to reduce the negative impact on the ecology of the area.
\end{abstract}

Keywords: Processing Shellfish, Shellfish waste, Kampung Kerang ljo, Ecology.

\section{PENDAHULUAN}

Kampung Kerang Ijio, Pesisir Muara Angke, Jakarta Utara, merupakan sebuah Kawasan dengan sebagian besar mata pencaharian sebagai Nelayan Kerang. Namun 2018 muncul isu penggusuran wilayah kampung tersebut karena terkena dampak reklamasi, selain itu dampak dari reklamasi tersebut menyebabkan rusaknya beberapa biota laut, diantaranya kerang hijau. Sedangkan nelayan di kawasan tersebut sangat bergantung dari hasil penangkapan kerang. Pendapatan masyarakat di kampung kerang ijo mengandalkan dari mengupas daging kerang dari kulitnya yang kemudian dijual di pasar. 
Ketika daging kerang telah terjual, munculah limbah kulit kerang yang bertumpuk menggunung di seluruh Kawasan Kampung Kerang ljo. Tumpukan kulit kerang tersebut membawa dampak buruk bagi manusia, dan dampak ekologi lingkungan fisik di Kawasan tersebut (Zahroh, Riani and Anwar 2019). Masalah-masalah yang muncul dari tumpukan limbah kulit kerang tersebut diantaranya Penurunan kesehatan masyarakat jika hal tersebut dibiarkan lebih lama lagi, sistem pernafasan juga terganggu akibat dari bau menyengat limbah kulit kerang tersebut dan mampu menyebabkan timbul penyakit ISPA (Infeksi Saluran Pernafasan Atas),

Pencemaran laut Teluk Jakarta disebabkan beberapa hal seperti (gambar 1) : Limbah Industri, Reklamasi, Limbah Rumah tangga, Usaha Migas, dan lain sebagainya yang dapat menyebabkan kematian ikan, terganggunya biota laut, gangguan kesehatan, menimbulkan efek gatal-gatal pada kulit juga akan muncul ketika masyarakat disana mengunakan air resapan tanah, Pencemaran Tanah yang mengakibatkan tanah tersebut tidak bisa ditanami tanaman penutup lahan (Asikin 1982).

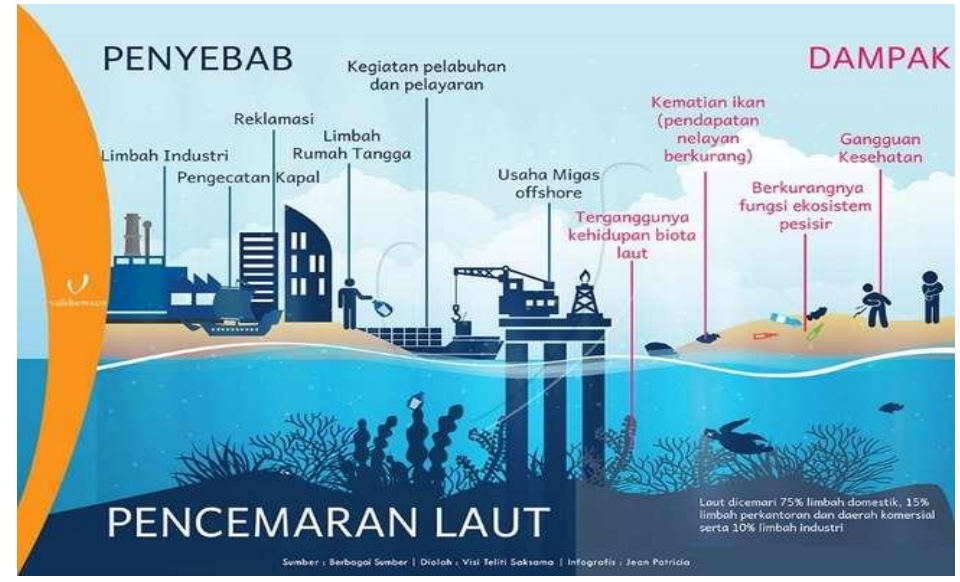

Gambar 1. Penyebab Pencemaran Laut

Sumber: https://oceanpulse-indonesia.com/pencemaran-laut-oleh-limbah-cair/, diunduh Juni 2020

Salah satu tempat penambakan kerang di Indonesia adalah Perairan Muara Angke, Teluk Jakarta. Kerang hijau (Mytilus viridis L.) dikonsumsi oleh manusia karena memiliki manfaat untuk memenuhi kebutuhan akan protein hewani (Cappenberg 2008). Hasil penelitian yang dilakukan pada bulan Juli 2005, menunjukkan bahwa logam berat dalam air laut di perairan Teluk Jakarta, di 8 stasiun yang diamati, berkisar 0,467 -0,817 mg/l, tingginya kandungan metal merkuri ini hampir mencapai batas maksimal kandungan metil merkuri yang aman yaitu $1 \mathrm{mg} / \mathrm{l}$, jika hal ini dilanggar tentu akan membahayakan mahkluk hidup yang ada disekitarnya.konsentrasi metil merkuri ini hampir menyentuh nilai ambang batas yang diijinkan (Winarno, Andayani and Sumartono 2009). Limbah Industri, dan rumah tangga mengandung logam berat yang berbahaya, limbah ini dialirkan dari sungai-sungai di Jakarta yang pada akhirnya bermuara di Teluk Jakarta (Warlina 2004). Salah satu penyumbang limbah logam berat tertinggi adalah limbah PLTU (Winarno, Andayani and Sumartono 2009).

Untuk itu proyek ini dirancang untuk mewadahi pengolahan dan penelitian berkelanjutan dari budidaya hingga proses pemanfaatan limbah kerang, dan berusaha menyelamatkan ekologi laut Teluk Jakarta dari dampak kontaminasi logam berat.

\section{KAJIAN LITERATUR} Beyond Ecology

Dalam bahasa Yunani, ekologi berasal dari dua kata yaitu oikos dan logos. Oikos yang diartikan sebagai rumah atau tempat tinggal, sedangkan logos memiliki arti ilmu atau pengetahuan. Organisme yang berada di tempat tinggalnya merupakan pengertian Ekologi secara harafiah. (Effendi, Salsabila and Malik 2018). 
Organisme yang saling berkaitan dan memiliki hubungan erat dengan lingkungannya adalah sebuah pengertian Ekologi. Seiring berkembangnya ilmu ekologi juga dapat diartikan sebagai ilmu dasar lingkungan, ilmu yang mempelajari bagimana mahkluk hidup tumbuh dan berkembang dan hubungan timbal balik antar mahkluk hidup dengan lingkungan sekitarnya (Effendi, Salsabila and Malik 2018). Keseimbangan dan kerhamonisan alam harus tetap terjaga karena kedua hal tersebut merupakan prinsip dasar Ekologi. Salah satu dampak tidak menjaga keseimbangan tersebut adalah terjadinya bencana alam. Ekologi juga melihat makhluk hidup memiliki perannya masing-masing.

Sedangkan pengertian dari "beyond" menurut kamus terjemahan adalah melebihi, melampaui sesuatu, melakukan sesuatu yang belum pernah dilakukan sebelumnya. Beyond Ecology adalah sebuah sistem baru yang baru dan lebih baik dari sebelumnya, lebih baik dari segi kehidupan, lingkungan fisik mapun non fisik. Beyond Ecology juga dapat didefinisikan sebagai sebuah kondisi ekosistem dengan kondisi formasi sosialnya yang sedang mengalami percepatan. Percepatan ini mempersingkat dan efisien sebuah kondisi ekosistem.

\section{Pengolahan Kerang}

Limbah padat kerang yang muncul dengan jumlah cukup besar sering terjadi karena kurangnya pengetahuan masyarakat tentang Pengolahan Kerang Hijau, hal ini tentu mampu membawa dampak buruk bagi kesehatan manusia dan lingkungan. Selama ini limbah padat kerang berupa cangkang hanya dimanfaatkan sebagai hiasan dinding, hasil kerajinan, atau bahkan sebagai campuran pakan ternak namun belum dimanfaatkan secara maksimal. Para Ilmuwan telah melakukan beberapa penelitian yang didalamnya menunjukkan bahwa cangkang kerang hijau mengandung zat kalsium yang cukup tinggi dan hal tersebut dapat dimanfaatkan sebagai vitamin ataupun suplemen tulang untuk mencegah osteoporosis. (Murdinah 2009). Pengamplasan Beton Kulit (gambar 2) Kerang juga dilakukan sebagai bentuk pengolahan kulit kerang. Pemanfaatan cangkang kerang hijau diharapkan dapat mengurangi sampah cangkang kerang yang menjadi sumber permasalahan bagi lingkungan (Murdinah 2009). Bangunan Pengolahan umumnya lebih mengutamakan efektivitas proses dan kegiatan daripada bentuk untuk memaksimalkan aktivitas pengolahan di dalamnya, untuk mencapai proses yang lebih maksimal umumnya proses ditata secara linier.

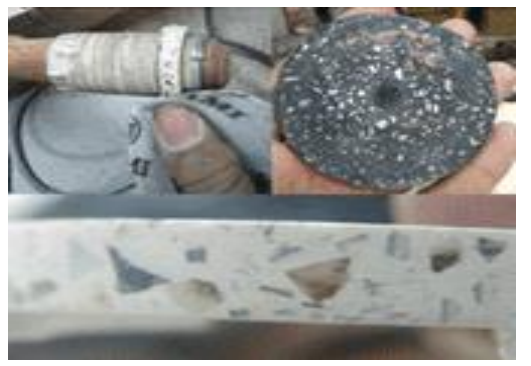

Gambar 2. Pengamplasan Beton Kulit Kerang

Sumber: Eksperimen material Alternatif untuk Produk Jam Tangan Kreatif: Eksplorasi

Motif Terrazzo dari Campuran Bahan Semen dan Limbah Kerang (Putra, Tristiyono and Hadi 2019)

\section{Pusat Penelitian}

Ruang Utama, inti, pangkal pokok yang menjadi tumpuan dan bersifat mengumpulkan merupakan pengertian dari Pusat (Kemendikbud 2021). Sedangkan sebuah Penelitian adalah kegiatan yang memiliki latar belakang ilmu, dan objek yang disebutkan harus berdasarkan fakta, terdapat hasil yang memiliki prinsip, dan didapatkan dari hasil kesimpulan akhir (Kemendikbud 2021). Maka arti Pusat Penelitian adalah suatu bangunan yang difungsikan sebagai tempat melakukan penelitian, membudidaya, dan mengembangkan suatu objek. (Kemendikbud 2021). 


\section{METODE}

\section{Programming Framework (gambar 3)}

Untuk merancang bangunan yang baik diperlukan penampilan yang baik, dan berfungsi secara maksimal. Tahap programming yang baik terdapat 5 (Lima) hal yang menjadi fokus diantaranya adalah (Pena and Parshall 2001):

\section{1) Establish Goals.}

2) Collect and analyze Facts.

3) Uncover and test Concepts.

4) Determine Needs.

5) State the Problem.

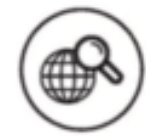

Prepare

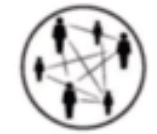

Establish Goals

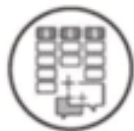

\section{Collect\&Analyze} Facts

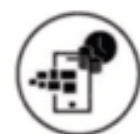

Determine Needs

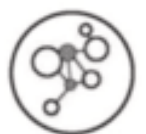

Uncover\&Test Concepts

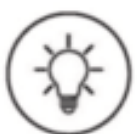

State the Problem

Gambar 3. Programming Framework

Sumber: Problem Seeking: An Architectural Programming Primer (Pena and Parshall 2001)

5 (Lima) Tahap tersebut dapat diterapkan di berbagai disiplin ilmu lainnya seperti teknik, edukasi, perbankan, dll. Terdapat 4 (Empat) hal yang dijadikan pertimbangan dalam dunia arsitektur dalam menentukan masalah di dunia arsitektur (gambar 4) diantaranya adalah (Pena and Parshall 2001):

1) Function: People, activities, relationships.

2) Form: Site, environment, quality.

3) Economy: Initial budget, operating costs, life cycle cost.

4) Time: Past, present, future.

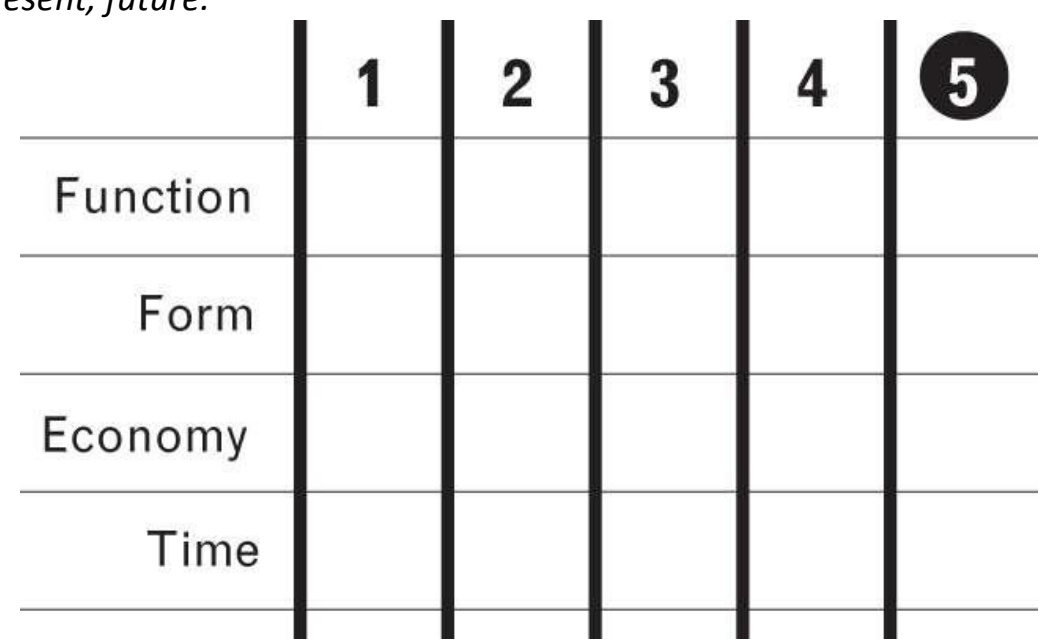

Gambar 4. Pertimbangan dalam menentukan masalah

Sumber: Problem Seeking: An Architectural Programming Primer (Pena and Parshall 2001)

Untuk menghasilkan rancangan bangunan menggunakan metode dengan melakukan analisis dari kondisi existing tapak dan dirangkai dalam diagram kawasan (gambar 5). Kondisi kawasan yang tercemar dibutuhkan tindakan pembersihan kawasan terlebih dahulu, dan penanaman tanaman Phytoremedian (Proses Bioremediasi untuk tanah yang terkontaminasi) Lalu menghasilkan program yang tepat untuk kawasan tersebut, dan Proses Analisis dari kondisi existing tapak tersebut juga menghasilkan bentuk/gubahan massa. Dengan adanya sungai existing nantinya akan dimanfaatkan sebagai kolam budidaya kerang. 


\section{DIAGRAM KAWASAN}
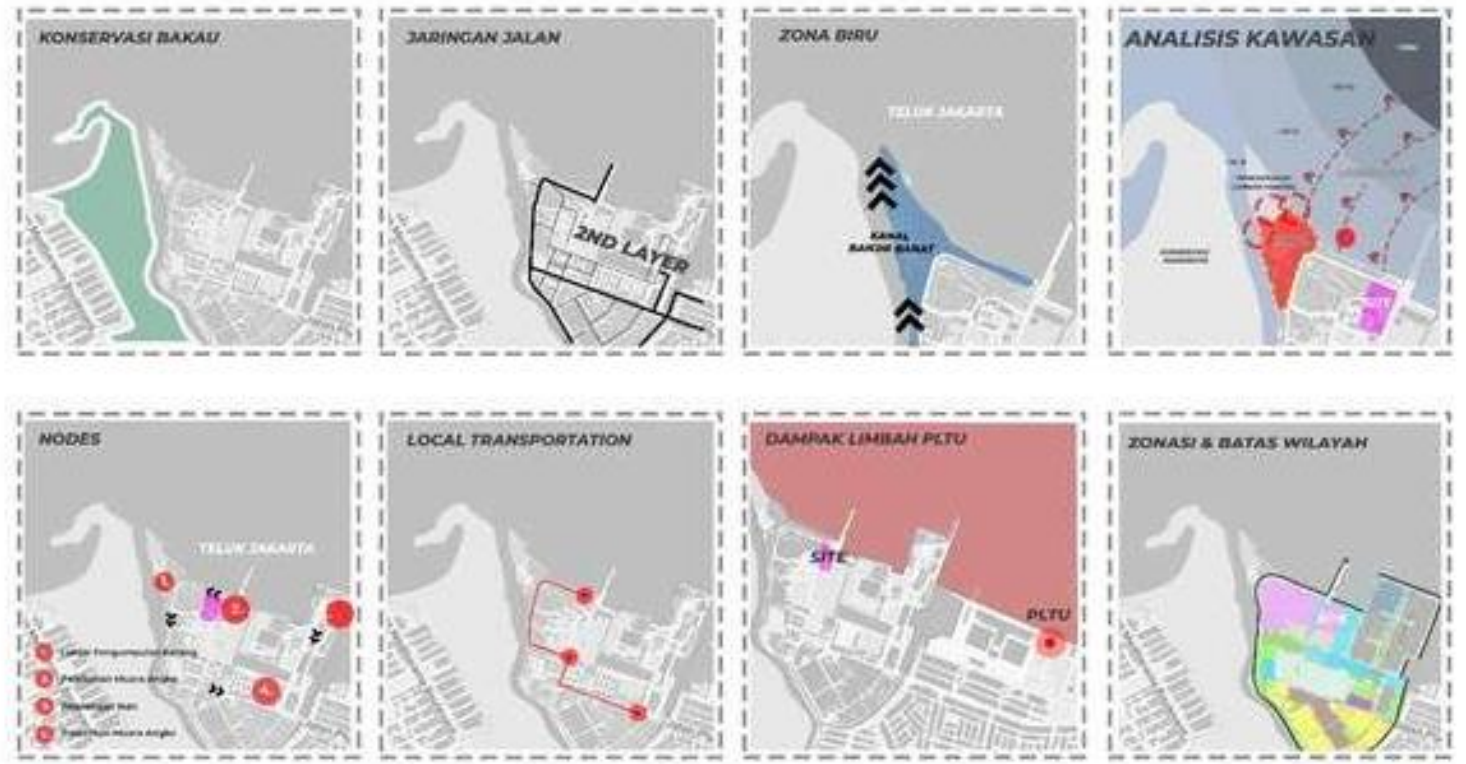

Gambar 5. Diagram Kawasan

Sumber: Penulis, 2021

Sedangkan untuk pengolahan limbah kulit kerang, dimulai dengan pemisahan daging kerang untuk dijual, dan kulit kerang. Kulit Kerang dihancurkan, yang kemudian menjadi bahan campuran untuk beton roster, sedangkan untuk campuran lantai terrazzo kulit kerang dihancurkan sebagian saja yang kemudian dicampur untuk menjadi finishing.

\section{DISKUSI DAN HASIL}

Dari beberapa teori para ahli, beyond ecology sebagai bentuk sistem yang baru dengan memperhatikan hubungannya dengan lingkungan sekitarnya. Pengolahan dan Penelitian sebagai wadah sarana yang memudahkan dan memberi pengetahuan tentang proses dan pengolahan kerang. Pengolahan ini bermanfaat mengurangi dampak buruk dari limbah kulit kerang yang menumpuk di kawasan tersebut. Oleh karena itu, wadah tersebut dirancang agar mampu menjadi contoh tempat pengolahan kerang dengan memperhatikan kondisi ekologi di lingkungan sekitar.

\section{Transformasi massa}

Analisis Konsep dan Bentuk rancangan disesuaikan dengan kondisi sekitar tapak dan mengutamakan efisiensi alur dan proses pengolahan kerang. Mulai dari Budidaya kerang, Mengolah daging Kerang, Mengolah Kulit Kerang hingga limbah yang dihasilkan lebih sedikit.

Proses Pembentukan massa (gambar 6) yang dilakukan, Pada site existing terdapat green area, sungai, dan building area berada diantaranya, kemudian massa bangunan dibagi dan dipisah menjadi 2 bagian yaitu bangunan penelitian, dan bangunan pengolahan kerang pemisahan zoning ini dilakukan untuk mengurangi dampak kebisingan, visualisasi, dan bau dari area pengolahan kerang, Lalu ditambahkan jembatan penghubung sebagai akses, dan look out area bagi pengunjung. Kemudian bangunan di bentuk berundak dari depan untuk view dari dalam maupun dari luar bangunan, setelah itu pada jalan dermaga ujung diberikan sebuah jembatan kinetik bagi mobil yang melintas agar pada jam tertentu perahu nelayan dapat melintasi sungai dibawahnya, kemudian bangunan pada area pameran di angkat agar mendapatkan pengudaraan, dan pencahayaan alami, Lalu proses terakhir yaitu memberikan second skin pada bagian barat bangunan untuk mengurangi panas matahari ketika sore hari.

Dengan proses ini diharapkan menjadi proyek "Beyond Ecology" bagi kawasan Kampung Kerang ljo. 


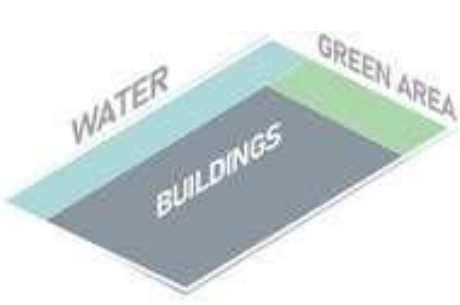

SITE

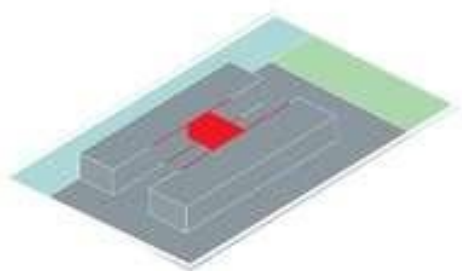

CONNECT

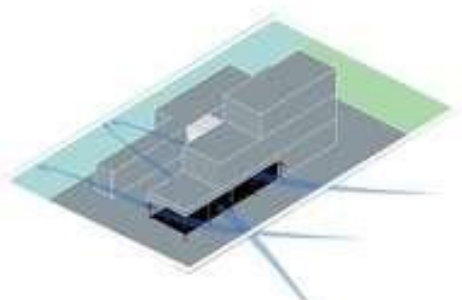

ELEVATE

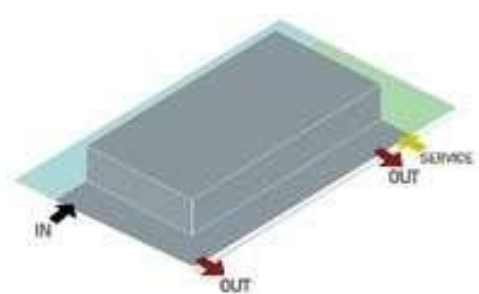

IN \& OUT

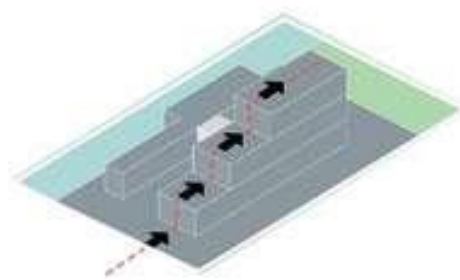

IN \& OUT

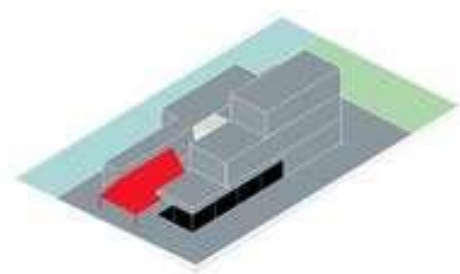

ENTRANCE

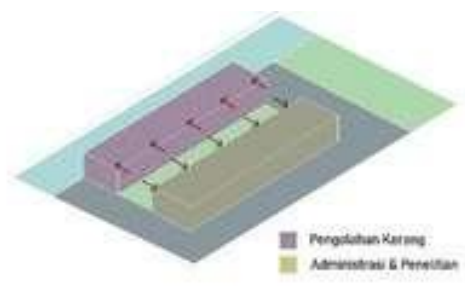

SPLIT

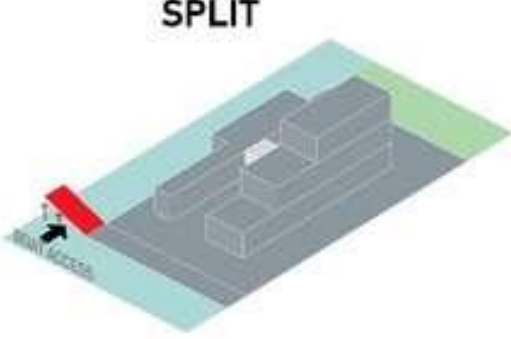

CAR BRIDGE

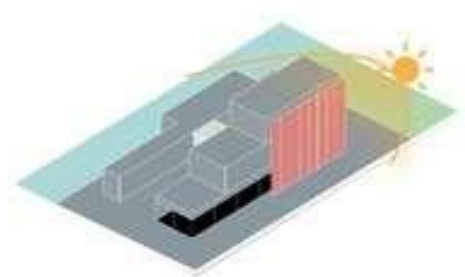

SKIN

Gambar 6. Proses Pembentukan Massa Sumber: Penulis, 2021

\section{Program}

Program dianalisis dari segi waktu, pola ruang, pelaku kegiatan yang disesuaikan dengan kategori, dan juga luasan ruang sesuai dengan kebutuhan desain agar proses yang pengolahan kerang dapat berjalan sesuai alur dan maksimal. Setelah melakukan beberapa kajian terhadap pola perilaku masyarakat Kampung Kerang ljo dan mencocokkan dengan data, fakta dan studi tentang Kampung Kerang ljo. Langkah selanjutnya adalah melakukan riset program kegiatan. Adanya langkah-langkah untuk melakukan programming diantaranya adalah mengumpulkan dan melakukan analisis terhadap fakta dan masalah yang ada di Kampung Kerang ljo, menentukan konsep apa yang dapat dibawa ke dalam proyek, mencari solusi untuk menyelesaikan masalah ke dalam rancangan.

Pembagian program (gambar 7) menjadi 2 yaitu program penelitian, dan pengolahan. Program Penelitian ditujukan untuk mengurangi dampak kontaminasi dengan program penelitian lanjut tentang bio polimer. Lalu Program pengolahan dibagi lagi menjadi 3 bagian yaitu before, in, after production phase. Before-Production phase merupakan program budidaya kerang sehingga ketika kerang dimanfaatkan tidak dengan mengeksploitasi alam, lalu In-Production phase merupakan program pengolahan daging kerang yang kemudian dikemas untuk dijual, sedangkan After-Production phase merupakan program pengolahan kulit kerang yang di daur ulang menjadi campuran material roster, dan keramik terazzo. Dengan adanya pengolahan limbah kulit kerang ini diharapkan mampu mengurangi jumlah limbah kulit kerang yang menumpuk disekitar kawasan.

Untuk menjawab permasalahan Kampung Kerang ljo dan menjawab tema soal yaitu Beyond Ecology. Program akan memiliki arah mendekatkan diri dengan berinteraksi secara langsung dengan alam, memperbaiki siklus pemanfaatan dan pengolahan kerang dan menghasilkan hubungan timbal balik yang positif. 


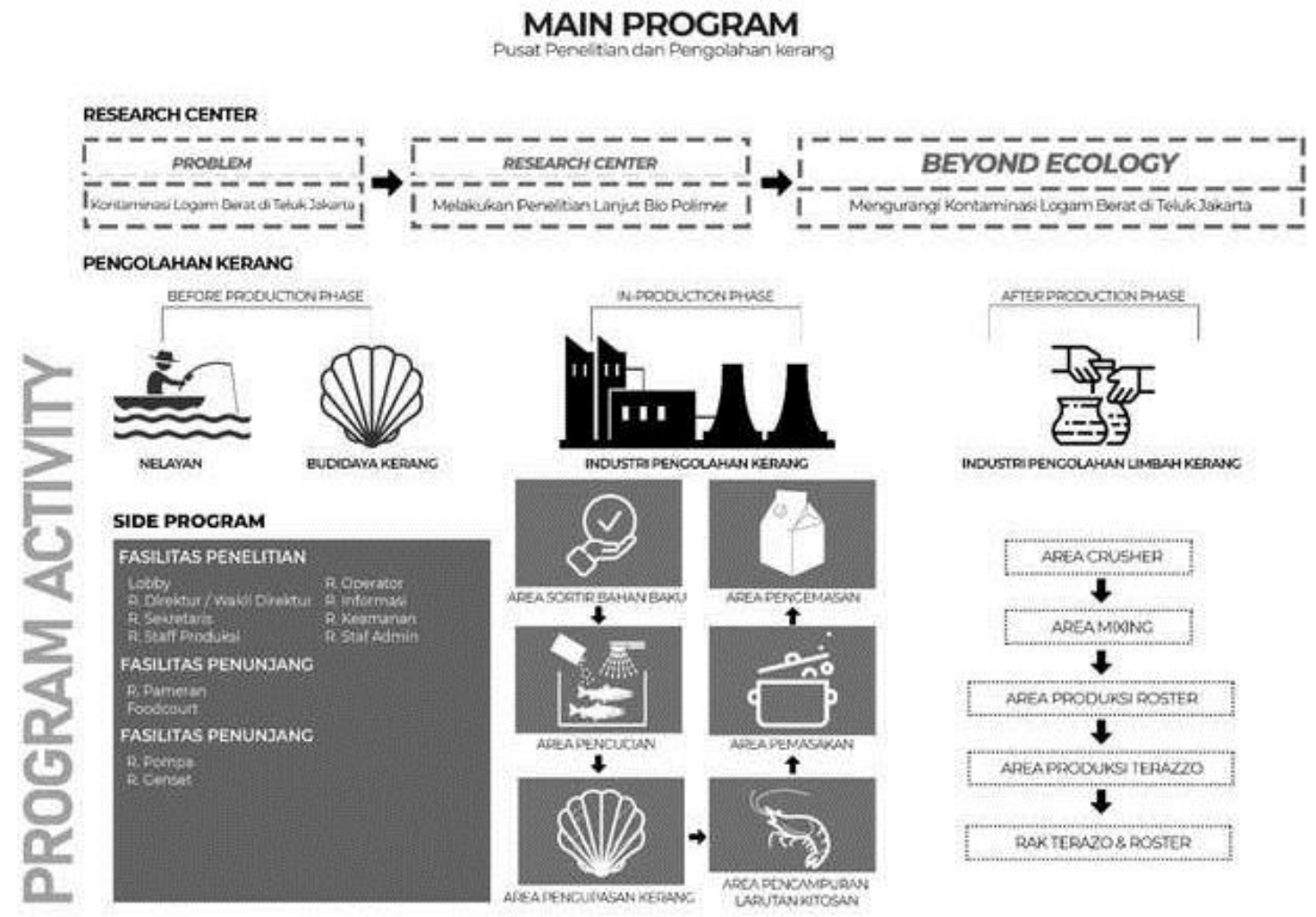

Gambar 7. Pembagian Program

Sumber: Penulis, 2021

\section{Sistem Struktur}

Sistem Struktur yang digunakan untuk atap pada bangunan pengolahan kerang adalah Portal Truss Frame (gambar 8). Dengan menggunakan jenis struktur ini fungsi pengolahan kerang dengan dapat dilakukan secara efisien, dan maksimal.

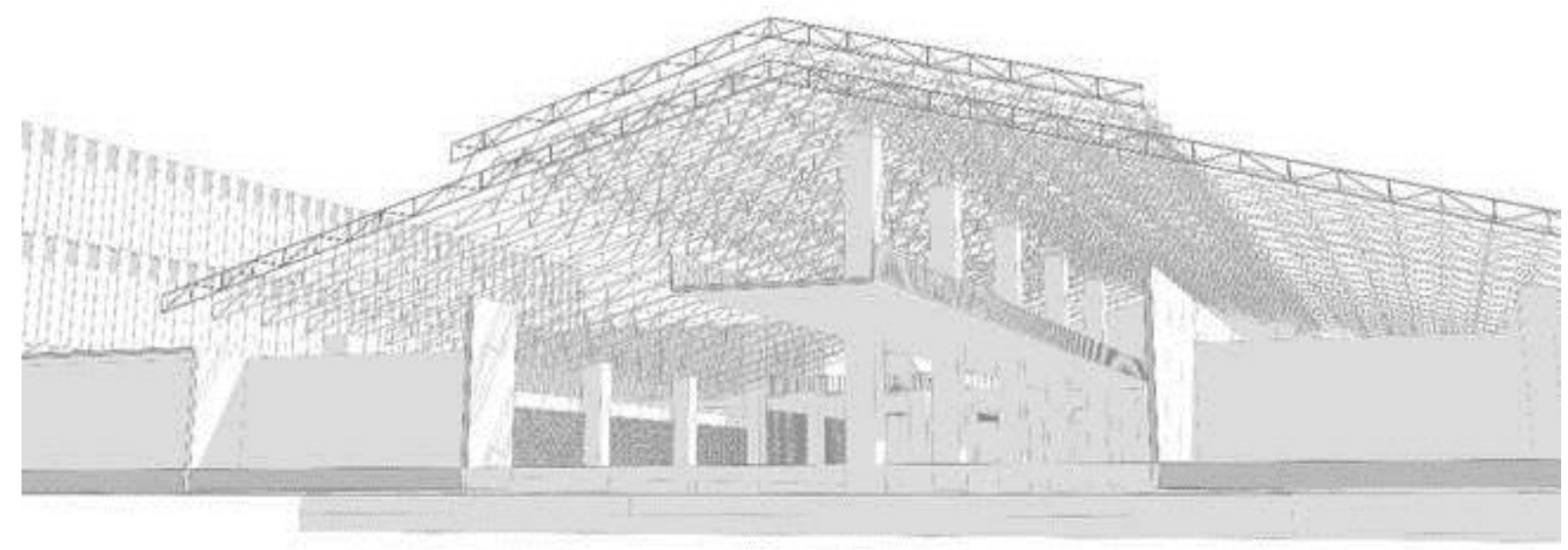

Gambar 8. Struktur Portal Truss Frame

Sumber: Penulis, 2021

Denah, Tampak, Potongan

Siteplan (gambar 9) menunjukkan area proses pengolahan kerang yang terhubung dengan zona perairan untuk memudahkan proses penerimaan kerang oleh nelayan, di atas area pengolahan kerang terdapat lookout area, untuk pengunjung melihat proses pengolahan kerang di bawahnya. Lalu pada bangunan penelitian terdapat area administrasi, dan area pameran untuk memamerkan hasil kerajinan olahan kerang. 


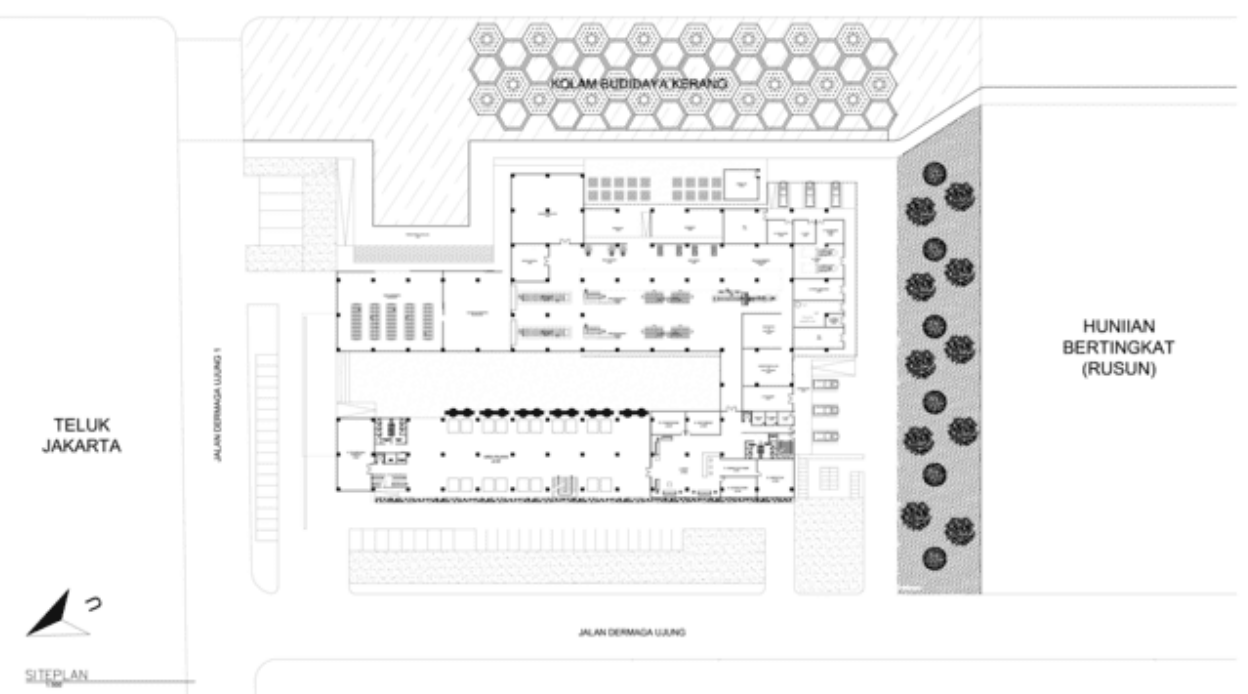

Gambar 9. Siteplan

Sumber: Penulis, 2021

Pada Denah Lantai 2 (gambar 10) merupakan area penelitian lanjut bahan Bio Polimer yang bermanfaat untuk mengurangi dampak kontaminasi Teluk Jakarta, dan lookout area, dimana pengunjung bisa melihat secara langsung proses pengolahan kerang yang berada dibawahnya.

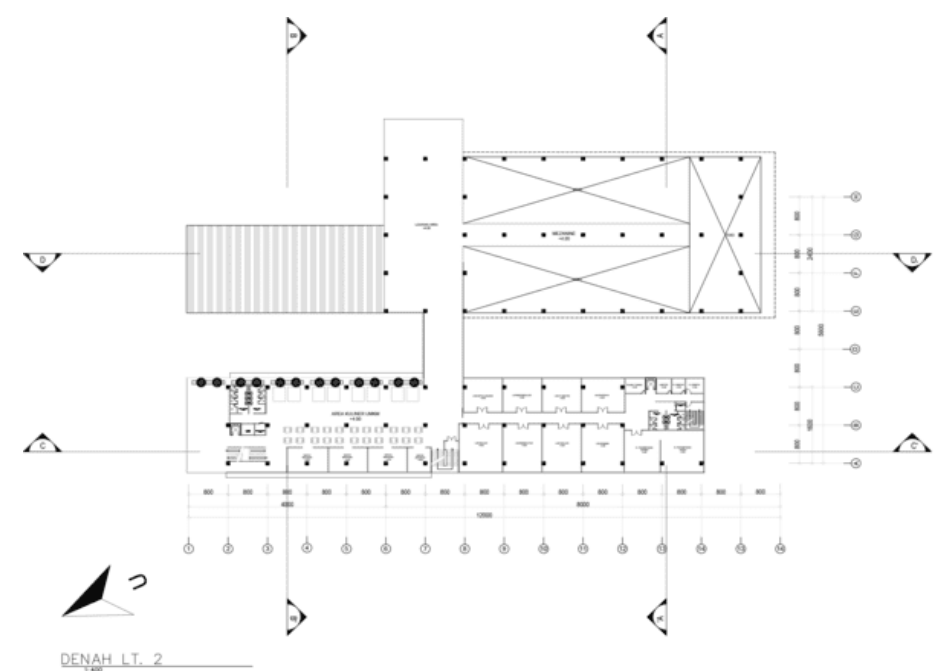

Gambar 10. Denah Lantai 2

Sumber: Penulis, 2021

Pada bagian tampak utara dan selatan (gambar 11) dapat terlihat sebuah jembatan kinetik yang akan diangkat ketika perahu nelayan masuk ke zona perairan dan budidaya kerang pada tapak. Entrance bangunan menghadap ke Teluk Jakarta dan arah datangnya kapal menuju ke Pelabuhan Kali Adem. 


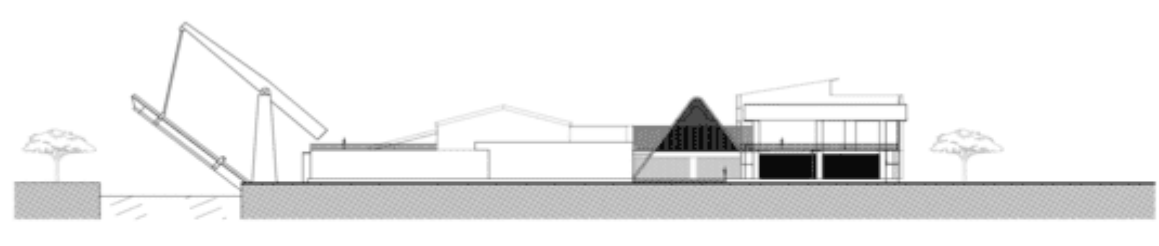

TAMPAK UTARA

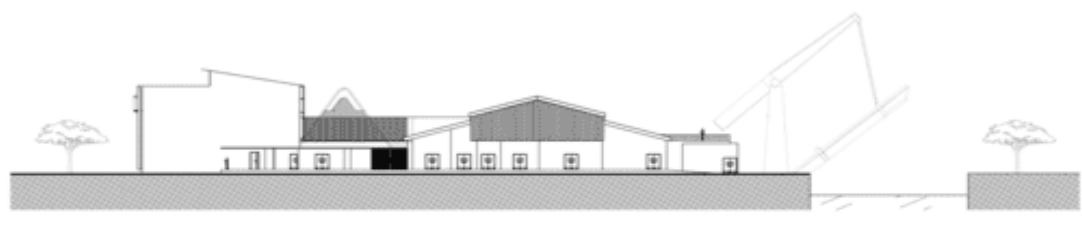

TAMPAK SELATAN

Gambar 11. Tampak Utara dan Selatan

Sumber: Penulis, 2021

Pada bagian potongan A-A dan potongan C-C (gambar 12) menunujukan struktur yang digunakan padabangunan pengolahan kerang menggunakan struktur Truss Portal Frame dengan bahan baja siku

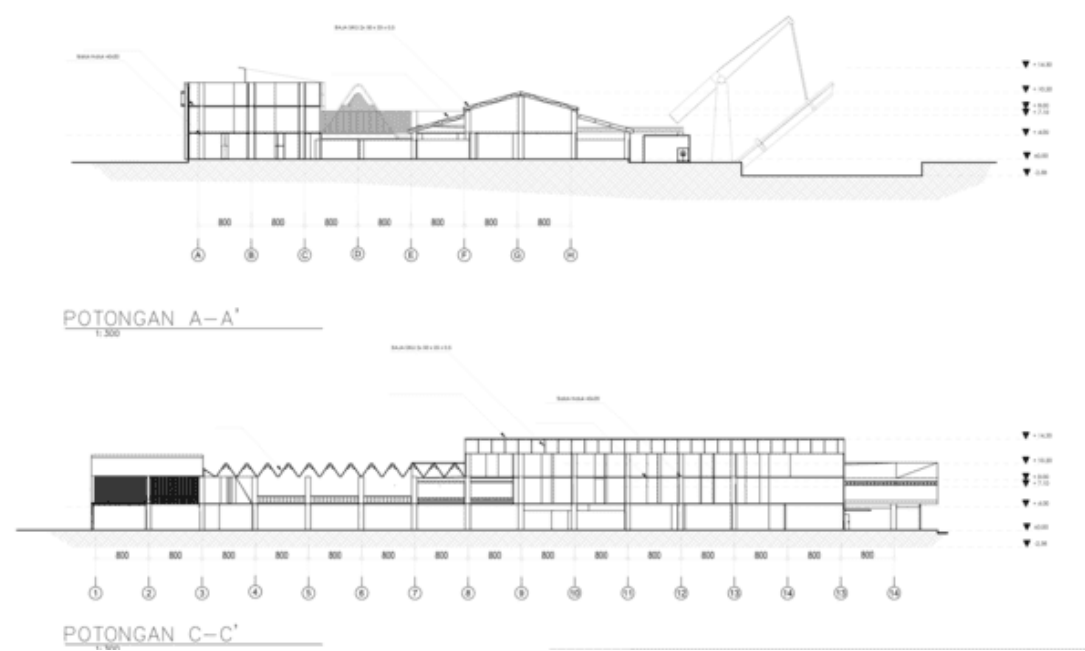

Gambar 12. Potongan A-A dan Potoongan C-C

Sumber: Penulis, 2021

Pada Perspektif eksterior (gambar 13) menunjukkan bagian bangunan entrance yang memiliki bentuk atap berbeda dengan sisi bangunan lainnya untuk menarik perhatian pengunjung yang datang. Kolam budidaya kerang, dan area parkir perahu nelayan yang berhubungan dekat dengan area pengolahan kerang. 

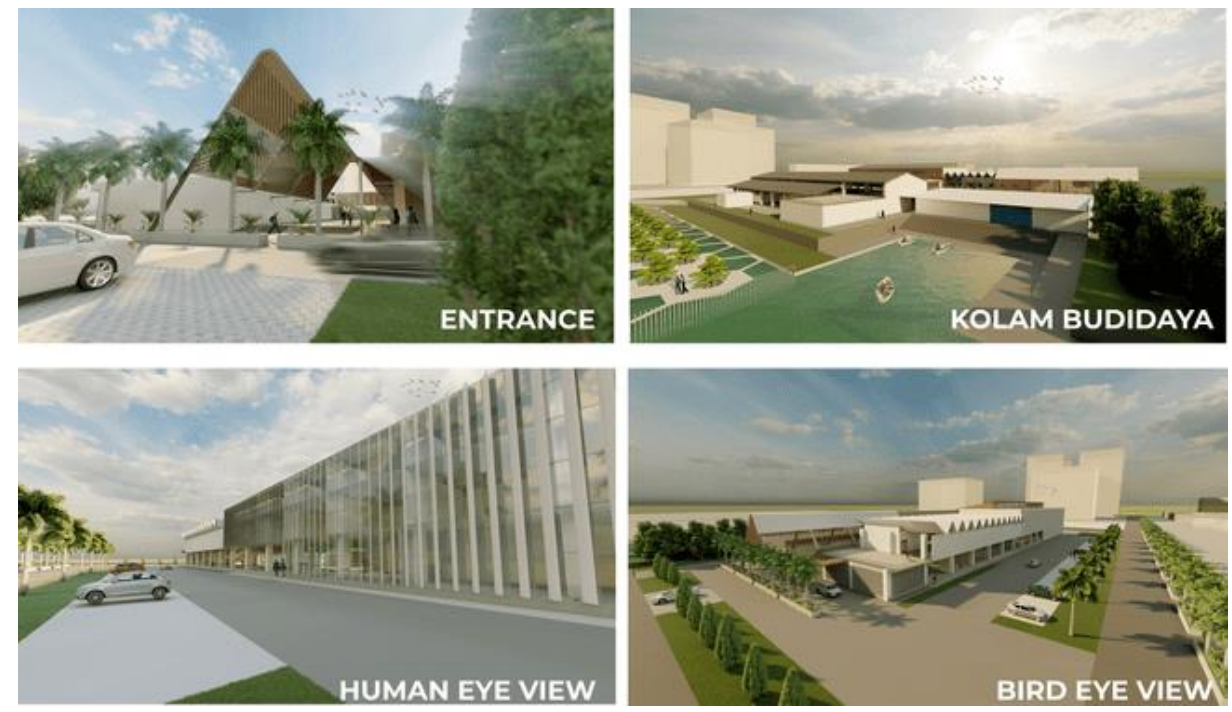

Gambar 13. Perspektif Eksterior

Sumber: Penulis, 2021

\section{KESIMPULAN}

Proyek ini memberikan wadah dan contoh bagaimana proses pengolahan dan penelitian kerang. Dimana permasalahan yang terjadi pada kawasan ini yaitu tumpukan kulit kerang dengan jumlah yang tinggi. Oleh karena itu proyek mencoba memperbaikinya dengan dimulai dari budidaya kerang, pemanfataan daging kerang, hingga pengelolaan kulit kerang dengan mengurangi tumpukan limbah kulit kerang yang tinggi. Sedangkan penelitian ditujukan untuk melakukan penelitian berkelanjutan tentang biopolimer yang diharapkan mampu menjadi solusi dalam mengurangi kontaminasi logam berat pada Teluk Jakarta. Sehingga proyek ini mampu dikembangkan lagi di berbagai tempat untuk memperbaiki siklus ekosistem yang mulai rusak.

\section{REFERENSI}

Asikin. (1982). Kerang Hijau - Pembudidayaan. Jakarta: Penebar Swadaya. http://lib.kemenperin.go.id/neo/detail.php?id=163203.

Cappenberg, Hendrik A.W. (2008). "Beberapa Aspek Biologi Reproduksi Kerang Hijau Perna viridis Linnaeus, 1758." 33-40.

Effendi, R., Hana S., and Abdul M. (2018). "Pemahaman tentang Lingkungan Berkelanjutan." Modul 18 (2): 75 82. doi:10.14710/mdl.18.2.2018.75-82.

Kemendikbud. (2021). Kamus Besar Bahasa Indonesia (KBBI). Februari 16. Accessed Juli 02, 2021. https://kbbi.web.id/penelitian.

Murdinah. (2009). "Penanganan dan Diversifikasi Produk Olahan Kerang Hijau." Squalen 4 (2): 61-71. https://www.bbp4b.litbang.kkp.go.id/squalen-bulletin/index.php/squalen/article/view/149/98.

Pena, W. M, and Steven A. Parshall. (2001). Problem Seeking: An Architectural Programming Primer. New York: John Wiley \& Sons.

Putra, Henry W. I., Bambang T., and Waluyo H. (2019). "Eksperimen material Alternatif untuk Produk Jam Tangan Kreatif: Eksplorasi Motif Terrazzo dari Campuran Bahan Semen dan Limbah Cangkang Kerang." Jurnal Sains dan Seni ITS 8 (2): 2337-3520. doi:10.12962/j23373520.v8i2.49641.

Warlina, L. (2004). "Pencemaran Air: Sumber, Dampak Dan Penanggulangannya." Juni. http://www.rudyct.com/PPS702-ipb/08234/lina_warlina.pdf.

Winarno, Ermin K., Winarti Andayani, and Agustin Sumartono. (2009). "Metil Merkuri dalam Kerang Hijau (Mytilus viridis L.) dari Pasar Pelelangan Ikan Muara Angke: Sebelum dan Setelah Pemasakan." Indo. J. Chem. 9 (1): 77-83.

Zahroh, A., Etty R., and Syaiful A. (2019). "Analisis Kualitas Perairan Untuk Budidaya Kerang Hijau di Kabupaten Cirebon Provinsi Jawa Barat." Jurnal Pengelolaan Sumberdaya Alam dan Lingkungan 9 (1): 86-91. doi:doi: 10.29244/jpsl.9.1.86-91.

https://oceanpulse-indonesia.com/pencemaran-laut-oleh-limbah-cair/ 